OPEN ACCESS

Edited by:

Raúl J. Gazmuri,

Rosalind Franklin University of Medicine and Science, United States

Reviewed by:

Longxiang Su,

Peking Union Medical College Hospital (CAMS), China

Mihaly Boros,

University of Szeged, Hungary

${ }^{*}$ Correspondence:

Nicholas Heming

nicholas.heming@aphp.fr

Specialty section: This article was submitted to Intensive Care Medicine and Anesthesiology

a section of the journal

Frontiers in Medicine

Received: 25 September 2019

Accepted: 13 December 2019

Published: 10 January 2020

Citation:

Heming N, Mazeraud A, Azabou E

Moine $P$ and Annane D (2020)

Vasopressor Therapy and the Brain:

Dark Side of the Moon.

Front. Med. 6:317.

doi: 10.3389/fmed.2019.00317

\section{Vasopressor Therapy and the Brain: Dark Side of the Moon}

\author{
Nicholas Heming ${ }^{1,2 \star}$, Aurélien Mazeraud ${ }^{3}$, Eric Azabou ${ }^{2,4}$, Pierre Moine ${ }^{1,2}$ and \\ Djillali Annane ${ }^{1,2}$ \\ ${ }^{1}$ General Intensive Care Unit, Raymond Poincaré Hospital, Garches, France, ${ }^{2}$ U1173 Lab Inflammation and Infection, \\ University of Versailles SQY-Paris Saclay - INSERM, Montigny-le-Bretonneux, France, ${ }^{3}$ Department of Neuro-Anesthesiology \\ and Intensive Care Medicine, Sainte-Anne Teaching Hospital, Paris-Descartes University, Paris, France, ${ }^{4}$ Department of \\ Physiology, Assistance Publique-Hôpitaux de Paris, Raymond-Poincaré Hospital, Garches, France
}

Sepsis, a leading cause of morbidity and mortality, is caused by a deregulated host response to pathogens, and subsequent life-threatening organ dysfunctions. All major systems, including the cardiovascular, respiratory, renal, hepatic, hematological, and the neurological system may be affected by sepsis. Sepsis associated neurological dysfunction is triggered by multiple factors including neuro-inflammation, excitotoxicity, and ischemia. Ischemia results from reduced cerebral blood flow, caused by extreme variations of blood pressure, occlusion of cerebral vessels, or more subtle defects of the microcirculation. International guidelines comprehensively describe the initial hemodynamic management of sepsis, revolving around the normalization of systemic hemodynamics and of arterial lactate. By contrast, the management of sepsis patients suffering from brain dysfunction is poorly detailed, the only salient point being mentioned is that sedation and analgesia should be optimized. However, sepsis and the hemodynamic consequences thereof as well as vasopressors may have severe untoward neurological consequences. The current review describes the general neurological complications, as well as the consequences of vasopressor therapy on the brain and its circulation and addresses methods for cerebral monitoring during sepsis.

Keywords: sepsis associated encephalopathy, delirium, coma, sepsis, septic shock

\section{INTRODUCTION}

Sepsis is characterized by life-threatening organ dysfunction following non-homeostatic host response to an infection (1). Sepsis associated encephalopathy (SAE), a transient and potentially reversible brain dysfunction, occurs during the course of sepsis of an extra neurological source. SAE is both a frequent and serious complication (2). Indeed, in sepsis, acute neurological dysfunction occurs in up to $70 \%$ of cases $(3,4)$. Altered mental status is a risk factor of poor outcome for infected patients in the emergency room or in the ward $(1,5)$. Imaging studies of the brain in SAE are in most cases unremarkable. Mechanisms underlying SAE include neuro-inflammation, excitotoxicity, and ischemia. Ischemia occurs because of macrocirculatory and/or microcirculatory defects. Vasopressors are a cornerstone of the management of septic shock. However, vasoactive drugs may have deleterious consequences on cerebral perfusion. We herein review how sepsis, per $s e$, may affect the brain, as well as the direct and indirect cerebral consequences of vasopressor therapy in sepsis. 


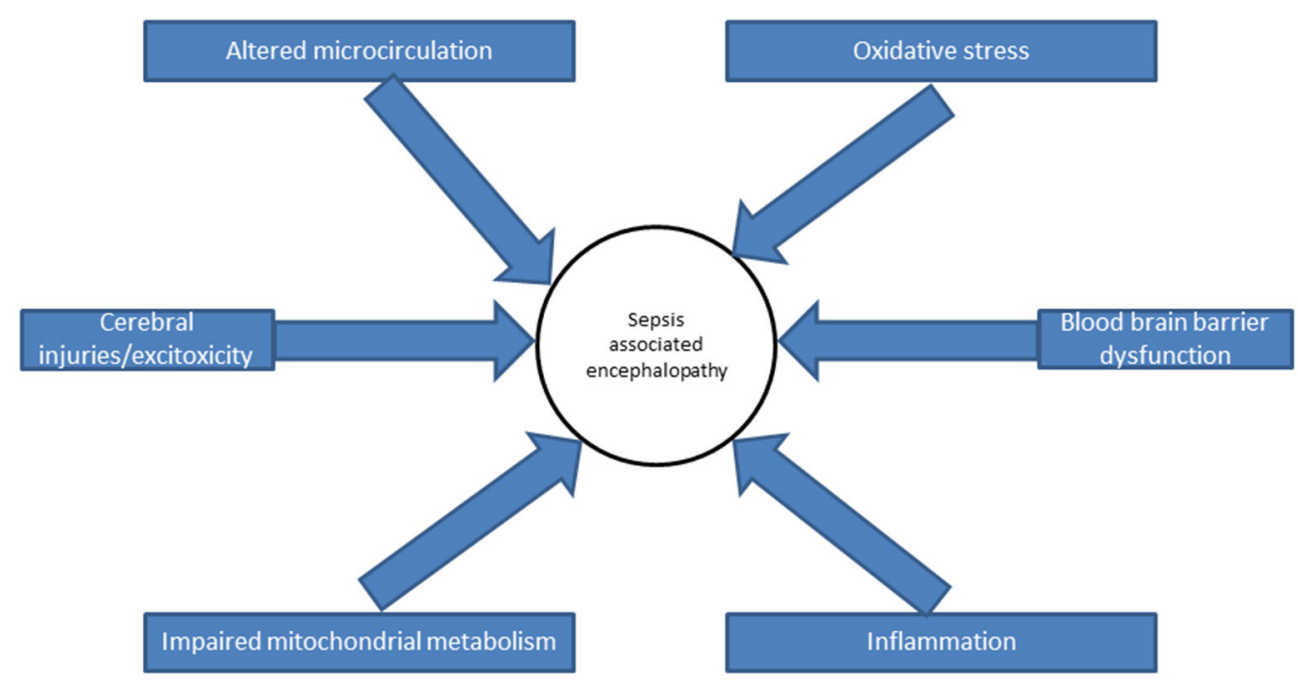

FIGURE 1 | Pathophysiology of sepsis associated encephalopathy.

\section{SEPSIS AND THE BRAIN}

Clinical features of SAE include sickness behavior, delirium and coma (6). Sickness behavior, the initial adaptive response to neuro-inflammation, results from the interaction of the inflammatory cytokines interleukin (IL)-1 alpha and IL-1 beta, tumor necrosis factor (TNF)-alpha and IL-6 on the brain. Sickness behavior associates apathy, asthenia, anorexia, and social withdrawal $(7,8)$. Delirium, characterized by fluctuating awareness and attention (9-11), presents as two distinctive entities, hyperactive delirium, which is easy to recognize but is fairly rare and hypoactive delirium which is frequent but may easily be overlooked (12). Delirium is detected at the bedside, using specific scales including the Confusion assessment method for the intensive care unit (CAM-ICU) or the Intensive Care Delirium Screening Checklist (ICDSC) $(11,13)$. Delirium is associated with prolonged mechanical ventilation, increased length of ICU stay and increased mortality (14). Medications, including Haloperidol, Ziprasidone, or Simvastatine all failed to reduce the duration of delirium in high quality randomized controlled trials $(15,16)$. The most severe form of neurological involvement in sepsis is coma which is linked to increased mortality and brainstem dysfunction (17-19). Neurological status is quantified using the Glasgow coma score or the FOUR score, which also assesses the brainstem function $(20,21)$. Sepsis survivors may suffer from long term neurological sequelae, including ICU-acquired paresis and cognitive impairment with subsequent functional disabilities and poor quality of life (22-24).

\section{PATHOPHYSIOLOGY OF SEPSIS ASSOCIATED ENCEPHALOPATHY (FIGURE 1)}

SAE results from several mechanisms, of which neuroinflammation, ischemia, and excitotoxicity are the main (25).

\section{Neuro-Inflammation}

The blood-brain barrier is formed by endothelial cells with tight junctions, astrocyte endfeet and pericytes and isolates the cerebral tissue from potentially noxious circulating components. Circulating inflammatory components freely interact with cerebral tissue devoid of blood-brain barrier, the circumventricular organs $(26,27)$. Circulating cytokines may also be shuttled across the blood-brain barrier by specialized carrier proteins (28-30). Peripheral inflammation is sensed and transmitted by the vagal nerve to neurovegetative centers and the limbic system. Neuro-inflammation is subsequently mediated by microglial cells, the resident macrophages of the brain and by astrocytes, which support neuronal functions (31). Microglial cells express membrane-bound receptors that detect damage associated molecular patterns, and induce cellular activation. Microglial activation occurs early in experimental models of sepsis $(32,33)$ and is characterized by the production of pro inflammatory cytokines, such as tumor necrosis factor alpha, interleukin-1 beta and transforming growth factor beta (34). Statins administered to reduce inflammation did not lower the incidence of delirium in septic patient (35).

Low cerebral reserves of anti-oxidants make the brain particularly vulnerable to oxidative stress. Anti-oxidant reserves are depleted during sepsis (36). Inflammation in sepsis induces early oxidative stress (37), which may be responsible for subsequent cognitive impairment (38). Anti-oxidant drugs reduce neuroinflammation in experimental models of sepsis $(39,40)$.

\section{Ischemia}

The adult human brain represents only $2 \%$ of the total body weight (41). Due to high metabolic demand, cerebral blood flow in healthy adults ranges from 750 to $900 \mathrm{ml} / \mathrm{min}$, accounting for $\sim 15 \%$ of an individual's resting cardiac output $(42,43)$. In physiological conditions, cerebral blood flow is modulated both at a macrocirculatory and microcirculatory level. Cerebral 
macrocirculation may be disrupted during sepsis, episodes of hypotension may alternate with hypertension leading to ischemic or hemorrhagic brain injuries $(31,44)$.

\section{Cerebral Macrocirculation}

Adequate cerebral blood flow is critical for the proper function of the brain. Cerebral autoregulation refers to the capacity to maintain a constant cerebral blood flow, independently of systemic arterial pressure. In man, autoregulation occurs for mean arterial pressures between 60 and $150 \mathrm{mmHg}$ (43). Beyond these values, cerebral blood flow becomes pressure-dependant and is therefore linearly correlated with cerebral perfusion pressure. Low mean arterial pressure leads to low cerebral blood flow. By contrast, excessive doses of vasoconstrictors may also lead to end-organ vasoconstriction and ischemia $(45,46)$.

Assessment of cerebral blood flow in septic patients is compounded by methodological difficulties. Most studies involve small populations and compare cerebral blood flow in sedated and ventilated septic patients to awake, non-septic control subjects $(47,48)$. A decrease in cerebral blood flow of the middle cerebral artery is consistently observed in experimental endotoxinemia $(49,50)$ and in sepsis (51-53). Such a decrease may be secondary to hyperventilation rather than the consequences of endotoxinemia/sepsis on cerebral hemodynamics. Sepsis also impairs cerebral autoregulation (54-57). Interestingly, decreased cerebral autoregulation in sepsis was found to be associated with delirium (58).

\section{Microcirculation}

Cerebral energetic requirements relate to the functioning of neurons, rather than that of glial supporting tissue. Indeed, the generation of neuronal action potentials, through the active transmembrane transport of ions, requires large quantities of energy. Cerebral blood flow is inhomogeneous, increasing in areas where neuronal activity is the greatest (59). The metabolic rate is greater in the gray matter of the brain, where most the cell bodies lie, than in the white matter (60). Adequate cerebral blood flow at the cellular level is obtained through a functioning gliovascular unit, associating endothelial cells, astrocytes and pericytes (61). Microcirculatory cerebral blood flow adaptation is modulated by hydrogen ion concentration, partial carbon dioxide pressure, partial oxygen pressure as well as neurotransmitter concentration and intracellular calcium concentration $(62,63)$. Increased carbon dioxide or hydrogen ion concentrations or hypoxia lead to cerebral vascular vasodilation and greater cerebral blood flow (64).

Sepsis, by injuring endothelial cells and inducing the production of NO disrupts the blood brain barrier, allowing leucocytes and inflammatory cytokines to penetrate the brain, which in turn leads to neuroinflammation, thereby promoting brain dysfunction (65-67). Ischemic or hemorrhagic lesions in the brain may occur in the presence of disseminated intravascular coagulopathy, affecting up to one critically ill patient out of five (68). In addition, sepsis is associated with mitochondrial dysfunction, leaving neurons unable to properly use oxygen $(69,70)$.
The association of macro and microcirculatory dysfunction compounded by an incapacity to respond to metabolic needs, contribute to the formation of cerebral ischemic lesions (24). Indeed, post mortem studies of the brain of septic patients found evidence of ischemic lesions (44), which may in part explain the high prevalence of disability in sepsis survivors (24). Another well-documented risk factor for ischemic stroke is atrial fibrillation (71). Large retrospective studies report an increased risk of new onset atrial fibrillation during sepsis. In a cohort of more than 60,000 septic patients, atrial fibrillation occurred during 25.5\% of hospitalizations (72). Prospective cohorts in the ICU confirmed the high incidence of new onset atrial fibrillation $(73,74)$. However, the exact prevalence of atrial fibrillation, which may be transient, is probably underestimated. Ischemic stroke is a major complication of atrial fibrillation (75). Large database studies report an increased risk of ischemic stroke associated with sepsis (75). Additionally, sepsis survivors having suffered from new onset atrial fibrillation exhibit a higher risk of subsequent stroke (76). Pathogens such as Mycoplasma pneumoniae are associated with an increased risk of stroke, possibly through immune mediated mechanisms (77). Other pathogens, including the varicella zoster virus, Treponema pallidum and Streptococcus pneumoniae may cause vasculopathy or vasculitis (78), while intracranial aneurysms or blebs, caused by an infection of the arterial wall are typically associated with Staphylococcus aureus or Streptococcus species endocarditis (79).

\section{Excitotoxicity}

During sepsis, neuronal and microglial apoptosis occur mainly in the amygdala, nucleus tractus solitarii and locus coeruleus (44). Excitotoxic neuronal apoptosis is mediated by glutamate, which is produced in large quantities by activated microglial cells (80). Cerebrospinal fluid glutamate concentration correlates with the neurological state during bacterial meningitis (81). The adjunction of glutamaterich cerebrospinal fluid to neuronal cell culture induces dose dependent cellular toxicity, which is attenuated by the adjunction of a NMDA receptor antagonist (82). Hydrogen sulfide and low doses of carbon monoxide also exhibit protective effects against glutamate-mediated neurotoxicity. Mitochondrial-mediated apoptosis occurs during sepsis, mediated by cellular pro-apoptotic factors $(83,84)$. Other pro-apoptotic factors, include, nitric oxide, $\mathrm{TNF} \alpha$, and hyperglycemia (85).

\section{Secondary Neurological Injuries Occurring During Sepsis}

Any organ dysfunction occurring during sepsis may affect the proper functioning of the brain. These include but are not limited to, circulatory or cerebral auto-regulation impairment, systemic organ (hepatic, renal, metabolic, or respiratory) failure as well as the direct or indirect consequences of medication side-effects (opioids, sedatives, antibiotics, sodium disorders...) and environmental factors (rest or lack thereof, light, and noise exposure) (6). 
CEREBRAL MONITORING DURING SEPSIS

Cerebral function assessment in sepsis is frequently overlooked. For instance, hypoactive delirium, while common, is underestimated. Means to accurately monitor the cerebral function at the bedside are not wildly available. Concomitant sedation may depress the brain function. No evidence or recommendation supports monitoring cerebral perfusion or function in septic patients (86). While the dose of vasopressors should be tailored to meet specific targets or surrogates of organ function, no guideline proposes neurological endpoints in sepsis. Nevertheless, several methods enable physicians to assess the cerebral function or perfusion. Methods used to assess cerebral function or perfusion include but are not limited to:

\section{- Clinical Scores}

The simplest mean of monitoring the brain in an awake patient is clinical. Acute brain dysfunction is identified using validated scales for delirium (i.e., ICSDC or CAM-ICU), coma (Glasgow Coma Scale) or brainstem reflexes in comatose patients (FOUR score) $(10,11,20,21)$. Vasopressors are rarely, if ever, titrated to clinical surrogates of brain dysfunction (87). Preliminary data seem to indicate that during sepsis mean arterial blood pressure of $80-85 \mathrm{mmHg}$ rather than $65-70 \mathrm{mmHg}$ may mitigate brain dysfunction (88).

\section{- Biomarkers}

Several biomarkers have been promoted to diagnose or manage brain injuries; including brain injuries of a septic origin. Elevated levels of protein S100B, neuron-specific enolase (NSE) or neurofilament have been reported during SAE. However, their use is controversial since extra-neurological tissues may also release these proteins (89-92).

\section{- Neuroimaging}

Cerebral blood flow may be noninvasively monitored by transcranial Doppler ultrasound at the bedside. Blood flow velocity in the cerebral mean artery, a surrogate for cerebral blood flow, is measured using sound waves. No impact of transcranial Doppler ultrasound use on patient centered outcomes has ever been demonstrated. Additionally, inadequate acoustic windows for transcranial doppler monitoring may occur in up to $10 \%$ of patients (93).

Neuroimaging, using computed tomography or magnetic resonance imaging of the brain may help demonstrate structural injury to the central nervous system. Imaging studies in septic patients with neurological involvement found evidence of white matter hyperdensities and of ischemic stroke (94-96). Such anomalies may be associated with long term cognitive impairment (24). Drawbacks of imaging studies include: impractical for continuous monitoring, do not accurately predict the functional state of the patient; and the most recent technology might not be available in every hospital.

Dynamic methods, including 18F-fluorodeoxyglucose (FDG) PET imaging and functional MRI go beyond a simple exploration of cerebral morphology by exploring cerebral activity. Dynamic neuroimaging techniques, while not routinely used, may be helpful in predicting long term outcomes in critically ill patients (97-99).

\section{- Electroencephalogram}

The electroencephalogram (EEG) records the neuronal electrical activity at the surface of the scalp; indirectly informing on the quality of cerebral perfusion. The EEG is non-invasive and easily available at the bedside (100). EEG patterns may be modified during sepsis. Continuous generalized triphasic waves and burst suppression are associated with the severity of brain dysfunction and with mortality (101). Delta-predominant background, absence of EEG reactivity, periodic discharges are independently associated with mortality $(102,103)$. However, none of these patterns are specific of sepsis.

\section{- Evoked Potentials}

Sensory evoked potentials are generated in response to somatosensory, visual or auditory stimuli. Evoked potentials may be obtained non-invasively at the bedside (100). Sensory evoked potentials explore the integrity of the peripheral or cranial nerve, the spinal cord and/or the brainstem, the thalamus and the cortex. Septic encephalopathy is associated with impaired somatosensory evoked potentials $(104,105)$. Prolonged nervous conduction times hint at an acute brain dysfunction and are prognostic markers in the critically ill $(106,107)$.

\section{- Intracranial Pressure}

The ideal mean of estimating brain perfusion at the bedside is through the assessment of cerebral perfusion pressure. Since the brain is enclosed in a rigid cranium, cerebral perfusion pressure (CPP) is related to mean arterial pressure (MAP) and intracranial pressure (ICP) by the equation $\mathrm{CPP}=\mathrm{MAP}-$ ICP. Brain injury leading to elevated ICP will reduce CPP if blood pressure remains identical. During severe brain injuries, vasopressors will maintain MAP but may also induce extreme vasoconstriction in the injured zones of the brain, lowering blood flow in these regions, thereby potentially worsening cerebral injuries (108). Optimal blood pressure strikes a delicate balance between transcapillary hydrostatic and oncotic forces and acceptable cerebral perfusion pressure (108). Only one study in sepsis assessed ICP without finding any evidence of intracranial hypertension (109). Intracranial pressure is almost never directly measured in sepsis, even in severe central nervous system infections, which are theoretically the most at risk of intracranial hypertension. Routine monitoring of intracranial pressure is not recommended in sepsis $(110,111)$.

\section{- Cerebral Oximetry}

Near-infrared spectroscopy uses the principle of light transmission and absorption to determine the tissue concentration of oxyhemoglobin and deoxyhemoglobin and to calculate tissue oxygen saturation. Cerebral oxygen saturation is measured at the frontal lobe and is used as a surrogate for cerebral blood flow. Decreased cerebral oxygen saturation during sepsis may be associated with an increased risk of death (112). Cerebral tissues oxygenation indexes assess 
cerebral autoregulation in septic patients (56). The exact role of cerebral oximetry for monitoring the cerebral function in sepsis needs to be defined (113).

\section{EFFECT OF VASOPRESSORS ON THE BRAIN \\ Direct Effect}

Moderate doses of norepinephrine increase cerebral vascular resistances and moderately decrease cerebral blood flow in isolated perfused dog brains (114). In healthy volunteers, norepinephrine lowers cerebral blood flow by increasing cerebral vascular resistances (115). The systemic administration of low doses of dopamine or norepinephrine in healthy piglets increases cerebral oxygenation $(116,117)$. High doses of norepinephrine administered to healthy rodents induce heterogeneous increases of cerebral blood flow and disruption of the blood brain barrier (118). The infusion of high doses of norepinephrine in healthy volunteers negatively affects cerebral oxygenation (45). The adjunctive administration of vasopressin in sepsis did not alter the number of days alive without neurological dysfunction (119). The systemic administration of moderate doses of angiotensin II to healthy pigs increases carotid blood flow; the effect on cerebral blood flow was not reported (120). The systemic administration of high doses of angiotensin to healthy baboons lead to disruption of the blood brain barrier and to ischemic brain lesions (121). In healthy humans, the intracarotid administration of angiotensin did not change regional cerebral blood flow $(122,123)$.

\section{Indirect Effect}

New onset atrial fibrillation in the ICU is linked to the presence of endogenous or exogenous vasopressors. A randomized

\section{REFERENCES}

1. Singer M, Deutschman CS, Seymour CW, Shankar-Hari M, Annane D, Bauer $\mathrm{M}$, et al. The Third International Consensus definitions for sepsis and septic shock (Sepsis-3). JAMA. (2016) 315:801-10. doi: 10.1001/ jama.2016.0287

2. Eidelman LA, Putterman D, Putterman C, Sprung CL. The spectrum of septic encephalopathy. Definitions, etiologies, and mortalities. JAMA. (1996) 275:470-3. doi: 10.1001/jama.275.6.470

3. Young GB, Bolton CF, Austin TW, Archibald YM, Gonder J, Wells GA. The encephalopathy associated with septic illness. Clin Invest Med. (1990) 13:297-304.

4. Sprung CL, Peduzzi PN, Shatney CH, Schein RM, Wilson MF, Sheagren JN, et al. Impact of encephalopathy on mortality in the sepsis syndrome. The Veterans Administration Systemic Sepsis Cooperative Study Group. Crit Care Med. (1990) 18:801-6. doi: 10.1097/00003246-19900 8000-00001

5. Freund Y, Lemachatti N, Krastinova E, Van Laer M, Claessens Y-E, Avondo A, et al. Prognostic accuracy of sepsis-3 criteria for in-hospital mortality among patients with suspected infection presenting to the emergency department. JAMA. (2017) 317:301-8. doi: 10.1001/jama.2016. 20329

6. Mazeraud A, Pascal Q, Verdonk F, Heming N, Chrétien F, Sharshar T. Neuroanatomy and physiology of brain dysfunction in sepsis. Clin Chest Med. (2016) 37:333-45. doi: 10.1016/j.ccm.2016.01.013 trial comparing the administration of norepinephrine plus dobutamine vs. epinephrine in the treatment of sepsis found that overall $2 \%$ of the population developed an ischemic stroke, and $1 \%$ of the population developed cerebral bleeding over the first 3 months (124). Both the incidence of supraventricular arrhythmia and of stroke was similar in patients treated by norepinephrine plus dobutamine vs. epinephrine (124). The incidence of cardiac arrhythmia is greater with dopamine than with norepinephrine $(125,126)$. The adjunctive administration of vasopressin in sepsis did not alter the prevalence of cerebrovascular accidents (119). The administration of angiotensin II in vasodilatory shock is not associated with an increased risk of brain injury (127).

Little data is available regarding goals for neuroprotection during sepsis. Higher blood pressure targets may be associated with mortality (128). Current guidelines indicate that the optimal MAP target to reduce mortality during sepsis is $65 \mathrm{mmHg}$ (86). MAP target personalization remains to be formally evaluated.

\section{CONCLUSIONS}

Neurological dysfunction is frequent during sepsis. Both sepsis and high dose vasopressor therapy may negatively impact cerebral perfusion and/or oxygenation. The best way to monitor and to manage patients suffering from sepsis-induced neurological dysfunction remains to be elucidated.

\section{AUTHOR CONTRIBUTIONS}

$\mathrm{NH}$ conceived the manuscript. $\mathrm{NH}, \mathrm{AM}, \mathrm{EA}, \mathrm{PM}$, and DA contributed to the literature search and wrote the manuscript.
7. Schedlowski M, Engler H, Grigoleit J-S. Endotoxin-induced experimental systemic inflammation in humans: a model to disentangle immuneto-brain communication. Brain Behav Immunity. (2014) 35:1-8. doi: 10.1016/j.bbi.2013.09.015

8. Dantzer R, O'Connor JC, Freund GG, Johnson RW, Kelley KW. From inflammation to sickness and depression: when the immune system subjugates the brain. Nat Rev Neurosci. (2008) 9:46-56. doi: 10.1038/nrn2297

9. Girard TD, Dittus RS, Ely EW. Critical illness brain injury. Annu Rev Med. (2016) 67:497-513. doi: 10.1146/annurev-med-050913-0 15722

10. Ely EW, Margolin R, Francis J, May L, Truman B, Dittus R, et al. Evaluation of delirium in critically ill patients: validation of the Confusion Assessment Method for the Intensive Care Unit (CAM-ICU). Crit Care Med. (2001) 29:1370-9. doi: 10.1097/00003246-200107000-00012

11. Bergeron N, Dubois MJ, Dumont M, Dial S, Skrobik Y. Intensive Care Delirium Screening Checklist: evaluation of a new screening tool. Intens Care Med. (2001) 27:859-64. doi: 10.1007/s001340100909

12. Peterson JF, Pun BT, Dittus RS, Thomason JWW, Jackson JC, Shintani AK, et al. Delirium and its motoric subtypes: a study of 614 critically Ill patients: delirium subtypes in the critically ill. J Am Geriatr Soc. (2006) 54:479-84. doi: 10.1111/j.1532-5415.2005.00621.x

13. Ely EW, Inouye SK, Bernard GR, Gordon S, Francis J, May L, et al. Delirium in mechanically ventilated patients: validity and reliability of the confusion assessment method for the intensive care unit (CAM-ICU). JAMA. (2001) 286:2703-10. doi: 10.1001/jama.286.21.2703 
14. Ely EW, Shintani A, Truman B, Speroff T, Gordon SM, Harrell FE, et al. Delirium as a predictor of mortality in mechanically ventilated patients in the intensive care unit. JAMA. (2004) 291:1753-62. doi: 10.1001/jama.291.14.1753

15. Page VJ, Casarin A, Ely EW, Zhao XB, McDowell C, Murphy L, et al. Evaluation of early administration of simvastatin in the prevention and treatment of delirium in critically ill patients undergoing mechanical ventilation (MoDUS): a randomised, double-blind, placebo-controlled trial. Lancet Respir Med. (2017) 5:727-37. doi: 10.1016/S2213-2600(17) 30234-5

16. Girard TD, Exline MC, Carson SS, Hough CL, Rock P, Gong MN, et al. Haloperidol and ziprasidone for treatment of delirium in critical illness. $N$ Engl J Med. (2018) 379:2506-16. doi: 10.1056/NEJMoa1808217

17. Vincent JL, de Mendonça A, Cantraine F, Moreno R, Takala J, Suter $\mathrm{PM}$, et al. Use of the SOFA score to assess the incidence of organ dysfunction/failure in intensive care units: results of a multicenter, prospective study. Working group on "sepsis-related problems" of the European Society of Intensive Care Medicine. Crit Care Med. (1998) 26:1793-800. doi: 10.1097/00003246-199811000-00016

18. Sharshar T, Porcher R, Siami S, Rohaut B, Bailly-Salin J, Hopkinson NS, et al. Brainstem responses can predict death and delirium in sedated patients in intensive care unit. Crit Care Med. (2011) 39:1960-7. doi: 10.1097/CCM.0b013e31821b843b

19. Rohaut B, Porcher R, Hissem T, Heming N, Chillet P, Djedaini $\mathrm{K}$, et al. Brainstem response patterns in deeply-sedated criticallyill patients predict 28-day mortality. PLOS ONE. (2017) 12:e0176012. doi: 10.1371/journal.pone.0176012

20. Teasdale G, Jennett B. Assessment of coma and impaired consciousness. A practical scale. Lancet. (1974) 2:81-4. doi: 10.1016/S0140-6736(74)91639-0

21. Wijdicks EFM, Bamlet WR, Maramattom BV, Manno EM, McClelland RL. Validation of a new coma scale: the FOUR score. Ann Neurol. (2005) 58:585-93. doi: 10.1002/ana.20611

22. Iwashyna TJ, Ely EW, Smith DM, Langa KM. Long-term cognitive impairment and functional disability among survivors of severe sepsis. JAMA. (2010) 304:1787-94. doi: 10.1001/jama.2010.1553

23. Ehlenbach WJ, Gilmore-Bykovskyi A, Repplinger MD, Westergaard RP, Jacobs EA, Kind AJH, et al. Sepsis survivors admitted to skilled nursing facilities: cognitive impairment, activities of daily living dependence, and survival. Crit Care Med. (2018) 46:37-44. doi: 10.1097/CCM.0000000000002755

24. Annane D, Sharshar T. Cognitive decline after sepsis. Lancet Respir Med. (2015) 3:61-9. doi: 10.1016/S2213-2600(14)70246-2

25. Heming N, Mazeraud A, Verdonk F, Bozza FA, Chrétien F, Sharshar T. Neuroanatomy of sepsis-associated encephalopathy. Crit Care. (2017) 21:65. doi: 10.1186/s13054-017-1643-z

26. Roth J, Harré E-M, Rummel C, Gerstberger R, Hübschle T. Signaling the brain in systemic inflammation: role of sensory circumventricular organs. Front Biosci. (2004) 9:290-300. doi: 10.2741/1241

27. Fry M, Ferguson AV. The sensory circumventricular organs: brain targets for circulating signals controlling ingestive behavior. Physiol Behav. (2007) 91:413-23. doi: 10.1016/j.physbeh.2007.04.003

28. Banks WA, Kastin AJ, Gutierrez EG. Penetration of interleukin-6 across the murine blood-brain barrier. Neurosci Lett. (1994) 179:53-6. doi: 10.1016/0304-3940(94)90933-4

29. Tracey KJ. The inflammatory reflex. Nature. (2002) 420:853-9. doi: 10.1038/nature01321

30. Pan W, Kastin AJ. TNFalpha transport across the blood-brain barrier is abolished in receptor knockout mice. Exp Neurol. (2002) 174:193-200. doi: 10.1006/exnr.2002.7871

31. Sharshar T, Annane D, de la Grandmaison GL, Brouland JP, Hopkinson NS, Françoise G. The neuropathology of septic shock. Brain Pathol. (2004) 14:21-33. doi: 10.1111/j.1750-3639.2004.tb00494.x

32. Henry CJ, Huang Y, Wynne AM, Godbout JP. Peripheral lipopolysaccharide (LPS) challenge promotes microglial hyperactivity in aged mice that is associated with exaggerated induction of both pro-inflammatory IL-1beta and anti-inflammatory IL-10 cytokines. Brain Behav Immun. (2009) 23:30917. doi: $10.1016 /$ j.bbi.2008.09.002
33. Hannestad J, Gallezot J-D, Schafbauer T, Lim K, Kloczynski T, Morris $\mathrm{ED}$, et al. Endotoxin-induced systemic inflammation activates microglia: $\left[{ }^{11} \mathrm{C}\right]$ PBR28 positron emission tomography in nonhuman primates. Neuroimage. (2012) 63:232-9. doi: 10.1016/j.neuroimage.2012.06.055

34. Semmler A, Hermann S, Mormann F, Weberpals M, Paxian SA, Okulla T, et al. Sepsis causes neuroinflammation and concomitant decrease of cerebral metabolism. J Neuroinflammation. (2008) 5:38. doi: 10.1186/1742-2094-5-38

35. Needham DM, Colantuoni E, Dinglas VD, Hough CL, Wozniak AW, Jackson JC, et al. Rosuvastatin versus placebo for delirium in intensive care and subsequent cognitive impairment in patients with sepsisassociated acute respiratory distress syndrome: an ancillary study to a randomised controlled trial. Lancet Respir Med. (2016) 4:203-12. doi: 10.1016/S2213-2600(16)00005-9

36. Voigt K, Kontush A, Stuerenburg H-J, Muench-Harrach D, Hansen HC, Kunze K. Decreased plasma and cerebrospinal fluid ascorbate levels in patients with septic encephalopathy. Free Radic Res. (2002) 36:735-9. doi: 10.1080/10715760290032557

37. Barichello T, Fortunato JJ, Vitali AM, Feier G, Reinke A, Moreira JCF, et al. Oxidative variables in the rat brain after sepsis induced by cecal ligation and perforation. Crit Care Med. (2006) 34:886-9. doi: 10.1097/01.CCM.0000201880.50116.12

38. d'Avila JC, Siqueira LD, Mazeraud A, Azevedo EP, Foguel D, CastroFaria-Neto HC, et al. Age-related cognitive impairment is associated with long-term neuroinflammation and oxidative stress in a mouse model of episodic systemic inflammation. J Neuroinflammation. (2018) 15:28. doi: 10.1186/s12974-018-1059-y

39. Della Giustina A, Goldim MP, Danielski LG, Florentino D, Mathias K, Garbossa L, et al. Alpha-lipoic acid attenuates acute neuroinflammation and long-term cognitive impairment after polymicrobial sepsis. Neurochem Int. (2017) 108:436-47. doi: 10.1016/j.neuint.2017.06.003

40. Godbout JP, Berg BM, Kelley KW, Johnson RW. alpha-Tocopherol reduces lipopolysaccharide-induced peroxide radical formation and interleukin-6 secretion in primary murine microglia and in brain. J Neuroimmunol. (2004) 149:101-9. doi: 10.1016/j.jneuroim.2003.12.017

41. Dekaban AS, Sadowsky D. Changes in brain weights during the span of human life: relation of brain weights to body heights and body weights. Ann Neurol. (1978) 4:345-56. doi: 10.1002/ana.410040410

42. Gore JC. Principles and practice of functional MRI of the human brain. JClin Invest. (2003) 112:4-9. doi: 10.1172/JCI200319010

43. Hall JE. Guyton and Hall Textbook of Medical Physiology, 13th ed. Philadelphia, PA: Elsevier (2016).

44. Sharshar T, Gray F, Lorin de la Grandmaison G, Hopkinson NS, Ross E, Dorandeu A, et al. Apoptosis of neurons in cardiovascular autonomic centres triggered by inducible nitric oxide synthase after death from septic shock. Lancet. (2003) 362:1799-805. doi: 10.1016/S0140-6736(03)14899-4

45. Brassard P, Seifert T, Secher NH. Is cerebral oxygenation negatively affected by infusion of norepinephrine in healthy subjects? Br J Anaesth. (2009) 102:800-5. doi: 10.1093/bja/aep065

46. Müller S, How O-J, Hermansen SE, Stenberg TA, Sager G, Myrmel T. Vasopressin impairs brain, heart and kidney perfusion: an experimental study in pigs after transient myocardial ischemia. Crit Care. (2008) 12:R20. doi: 10.1186/cc6794

47. Maekawa T, Fujii Y, Sadamitsu D, Yokota K, Soejima Y, Ishikawa T, et al. Cerebral circulation and metabolism in patients with septic encephalopathy. Am J Emerg Med. (1991) 9:139-43. doi: 10.1016/0735-6757(91)90175-J

48. Bowton DL, Bertels NH, Prough DS, Stump DA. Cerebral blood flow is reduced in patients with sepsis syndrome. Crit Care Med. (1989) 17:399-403. doi: 10.1097/00003246-198905000-00004

49. Møller K, Strauss GI, Qvist J, Fonsmark L, Knudsen GM, Larsen FS, et al. Cerebral blood flow and oxidative metabolism during human endotoxemia. J Cereb Blood Flow Metab. (2002) 22:1262-70. doi: 10.1097/01.WCB.0000037999.34930.CA

50. van den Brule JMD, Stolk R, Vinke EJ, van Loon LM, Pickkers P, et al. Vasopressors do not influence cerebral critical closing pressure during systemic inflammation evoked by experimental endotoxemia and sepsis in humans. SHOCK. (2018) 49:529-35. doi: 10.1097/SHK.00000000 00001003 
51. Terborg C, Schummer W, Albrecht M, Reinhart K, Weiller C, Röther J. Dysfunction of vasomotor reactivity in severe sepsis and septic shock. Intens Care Med. (2001) 27:1231-4. doi: 10.1007/s001340101005

52. Kadoi Y, Saito S, Kawauchi C, Hinohara H, Kunimoto F. Comparative effects of propofol vs dexmedetomidine on cerebrovascular carbon dioxide reactivity in patients with septic shock. Br J Anaesthesia. (2008) 100:224-9. doi: 10.1093/bja/aem343

53. Fülesdi B, Szatmári S, Antek C, Fülep Z, Sárkány P, Csiba L, et al. Cerebral vasoreactivity to acetazolamide is not impaired in patients with severe sepsis. J Crit Care. (2012) 27:337-43. doi: 10.1016/j.jcrc.2011.11.002

54. Crippa IA, Subirà C, Vincent J-L, Fernandez RF, Hernandez SC, Cavicchi FZ, et al. Impaired cerebral autoregulation is associated with brain dysfunction in patients with sepsis. Critical Care. (2018) 22:327. doi: 10.1186/s13054-018-2258-8

55. Schramm P, Klein KU, Falkenberg L, Berres M, Closhen D, Werhahn KJ, et al. Impaired cerebrovascular autoregulation in patients with severe sepsis and sepsis-associated delirium. Crit Care. (2012) 16:R181. doi: 10.1186/ cc11665

56. Steiner LA, Pfister D, Strebel SP, Radolovich D, Smielewski P, Czosnyka M. Near-infrared spectroscopy can monitor dynamic cerebral autoregulation in adults. Neurocrit Care. (2009) 10:122-8. doi: 10.1007/s12028-0 08-9140-5

57. Taccone FS, Castanares-Zapatero D, Peres-Bota D, Vincent J-L, Berre' J, Melot C. Cerebral autoregulation is influenced by carbon dioxide levels in patients with septic shock. Neurocrit Care. (2010) 12:35-42. doi: 10.1007/s12028-009-9289-6

58. Pfister D, Siegemund M, Dell-Kuster S, Smielewski P, Rüegg S, Strebel SP, et al. Cerebral perfusion in sepsis-associated delirium. Crit Care. (2008) 12:R63. doi: 10.1186/cc6891

59. Paulson OB, Hasselbalch SG, Rostrup E, Knudsen GM, Pelligrino D. Cerebral blood flow response to functional activation. J Cereb Blood Flow Metab. (2010) 30:2-14. doi: 10.1038/jcbfm.2009.188

60. An H, Lin W, Celik A, Lee YZ. Quantitative measurements of cerebral metabolic rate of oxygen utilization using MRI: a volunteer study. NMR Biomed. (2001) 14:441-7. doi: 10.1002/nbm.717

61. Abbott NJ, Rönnbäck L, Hansson E. Astrocyte-endothelial interactions at the blood-brain barrier. Nat Rev Neurosci. (2006) 7:41-53. doi: 10.1038/ nrn1824

62. Harper AM, Glass HI. Effect of alterations in the arterial carbon dioxide tension on the blood flow through the cerebral cortex at normal and low arterial blood pressures. J Neurol Neurosurg Psychiatry. (1965) 28:449-52. doi: 10.1136/jnnp.28.5.449

63. Panerai RB, Dineen NE, Brodie FG, Robinson TG. Spontaneous fluctuations in cerebral blood flow regulation: contribution of PaCO2. J Appl Physiol. (2010) 109:1860-8. doi: 10.1152/japplphysiol.00857.2010

64. Regan RE, Fisher JA, Duffin J. Factors affecting the determination of cerebrovascular reactivity. Brain Behav. (2014) 4:775-88. doi: $10.1002 /$ brb3.275

65. Papadopoulos MC, Lamb FJ, Moss RF, Davies DC, Tighe D, Bennett ED. Faecal peritonitis causes oedema and neuronal injury in pig cerebral cortex. Clin Sci. (1999) 96:461-6. doi: 10.1042/cs0960461

66. Ari I, Kafa IM, Kurt MA. Perimicrovascular edema in the frontal cortex in a rat model of intraperitoneal sepsis. Exp Neurol. (2006) 198:242-9. doi: 10.1016/j.expneurol.2005.12.001

67. Handa O, Stephen J, Cepinskas G. Role of endothelial nitric oxide synthasederived nitric oxide in activation and dysfunction of cerebrovascular endothelial cells during early onsets of sepsis. Am J Physiol Heart Circ Physiol. (2008) 295:H1712-19. doi: 10.1152/ajpheart.00476.2008

68. Vincent J-L, Castro P, Hunt BJ, Jörres A, Praga M, Rojas-Suarez J, et al. Thrombocytopenia in the ICU: disseminated intravascular coagulation and thrombotic microangiopathies-what intensivists need to know. Crit Care. (2018) 22:158. doi: 10.1186/s13054-018-2073-2

69. Brealey D, Brand M, Hargreaves I, Heales S, Land J, Smolenski $\mathrm{R}$, et al. Association between mitochondrial dysfunction and severity and outcome of septic shock. Lancet. (2002) 360:219-23. doi: 10.1016/S0140-6736(02)09459-X

70. Comim CM, Rezin GT, Scaini G, Di-Pietro PB, Cardoso MR, Petronilho FC, et al. Mitochondrial respiratory chain and creatine kinase activities in rat brain after sepsis induced by cecal ligation and perforation. Mitochondrion. (2008) 8:313-18. doi: 10.1016/j.mito.2008.07.002

71. Mehta S, Cook D, Devlin JW, Skrobik Y, Meade M, Fergusson $\mathrm{D}$, et al. Prevalence, risk factors, and outcomes of delirium in mechanically ventilated adults*. Crit Care Med. (2015) 43:557-66. doi: 10.1097/CCM.0000000000000727

72. Walkey AJ, Greiner MA, Heckbert SR, Jensen PN, Piccini JP, Sinner MF, et al. Atrial fibrillation among Medicare beneficiaries hospitalized with sepsis: incidence and risk factors. Am Heart J. (2013) 165:949-55.e3. doi: 10.1016/j.ahj.2013.03.020

73. Klein Klouwenberg PMC, Frencken JF, Kuipers S, Ong DSY, Peelen LM, van Vught LA, et al. Incidence, predictors, and outcomes of new-onset atrial fibrillation in critically ill patients with sepsis. a cohort study. Am J Respir Crit Care Med. (2017) 195:205-11. doi: 10.1164/rccm.2016030618OC

74. Meierhenrich R, Steinhilber E, Eggermann C, Weiss M, Voglic S, Bögelein $\mathrm{D}$, et al. Incidence and prognostic impact of new-onset atrial fibrillation in patients with septic shock: a prospective observational study. Crit Care. (2010) 14:R108. doi: 10.1186/cc9057

75. Walkey AJ, Wiener RS, Ghobrial JM, Curtis LH, Benjamin EJ. Incident stroke and mortality associated with new-onset atrial fibrillation in patients hospitalized with severe sepsis. JAMA. (2011) 306:2248-54. doi: 10.1001/jama.2011.1615

76. Walkey AJ, Hammill BG, Curtis LH, Benjamin EJ. Long-term outcomes following development of new-onset atrial fibrillation during sepsis. Chest. (2014) 146:1187-95. doi: 10.1378/chest.14-0003

77. Mélé N, Turc G. Stroke associated with recent mycoplasma pneumoniae infection: a systematic review of clinical features and presumed pathophysiological mechanisms. Front Neurol. (2018) 9:1109. doi: 10.3389/fneur.2018.01109

78. Katchanov J, Siebert E, Klingebiel R, Endres M. Infectious vasculopathy of intracranial large- and medium-sized vessels in neurological intensive care unit: a clinico-radiological study. Neurocrit Care. (2010) 12:369-74. doi: 10.1007/s12028-010-9335-4

79. Ducruet AF, Hickman ZL, Zacharia BE, Narula R, Grobelny BT, Gorski J, et al. Intracranial infectious aneurysms: a comprehensive review. Neurosurg Rev. (2010) 33:37-46. doi: 10.1007/s10143-009-0233-1

80. Takeuchi H, Jin S, Wang J, Zhang G, Kawanokuchi J, Kuno R, et al. Tumor necrosis factor-alpha induces neurotoxicity via glutamate release from hemichannels of activated microglia in an autocrine manner. J Biol Chem. (2006) 281:21362-8. doi: 10.1074/jbc.M600504200

81. Spranger M, Schwab S, Krempien S, Winterholler M, Steiner T, Hacke W. Excess glutamate levels in the cerebrospinal fluid predict clinical outcome of bacterial meningitis. Arch Neurol. (1996) 53:992-6. doi: 10.1001/archneur.1996.00550100066016

82. Spranger M, Krempien S, Schwab S, Maiwald M, Bruno K, Hacke W. Excess glutamate in the cerebrospinal fluid in bacterial meningitis. J Neurol Sci. (1996) 143:126-31. doi: 10.1016/S0022-510X(96)00197-9

83. Semmler A, Okulla T, Sastre M, Dumitrescu-Ozimek L, Heneka MT. Systemic inflammation induces apoptosis with variable vulnerability of different brain regions. J Chem Neuroanat. (2005) 30:144-57. doi: 10.1016/j.jchemneu.2005.07.003

84. Comim CM, Barichello T, Grandgirard D, Dal-Pizzol F, Quevedo J, Leib SL. Caspase-3 mediates in part hippocampal apoptosis in sepsis. Mol Neurobiol. (2013) 47:394-8. doi: 10.1007/s12035-012-8354-x

85. Polito A, Brouland J-P, Porcher R, Sonneville R, Siami S, Stevens RD, et al. Hyperglycaemia and apoptosis of microglial cells in human septic shock. Crit Care. (2011) 15:R131. doi: 10.1186/cc10244

86. Rhodes A, Evans LE, Alhazzani W, Levy MM, Antonelli M, Ferrer R, et al. Surviving sepsis campaign: international guidelines for management of sepsis and septic shock: 2016. Intens Care Med. (2017) 43:304-77. doi: 10.1007/s00134-017-4683-6

87. St-Arnaud C, Ethier J-F, Hamielec C, Bersten A, Guyatt G, Meade M, et al. Prescribed targets for titration of vasopressors in septic shock: a retrospective cohort study. CMAJ Open. (2013) 1:E127-33. doi: 10.9778/cmajo.20 130006

88. Jouan Y, Seegers V, Meziani F, Grelon F, Megarbane B, Anguel N, et al. Effects of mean arterial pressure on arousal in sedated ventilated patients with septic 
shock: a SEPSISPAM post hoc exploratory study. Ann Intens Care. (2019) 9:54. doi: 10.1186/s13613-019-0528-5

89. Piazza O, Cotena S, De Robertis E, Caranci F, Tufano R. Sepsis associated encephalopathy studied by MRI and cerebral spinal fluid S100B measurement. Neurochem Res. (2009) 34:1289-92. doi: 10.1007/s11064-008-9907-2

90. Piazza O, Russo E, Cotena S, Esposito G, Tufano R. Elevated S100B levels do not correlate with the severity of encephalopathy during sepsis. Br J Anaesth. (2007) 99:518-21. doi: 10.1093/bja/aem201

91. Grandi C, Tomasi CD, Fernandes K, Stertz L, Kapczinski F, Quevedo $\mathrm{J}$, et al. Brain-derived neurotrophic factor and neuron-specific enolase, but not $S 100 \beta$, levels are associated to the occurrence of delirium in intensive care unit patients. J Crit Care. (2011) 26:133-37. doi: 10.1016/j.jcrc. 2010.10.006

92. Ehler J, Petzold A, Wittstock M, Kolbaske S, Gloger M, Henschel J, et al. The prognostic value of neurofilament levels in patients with sepsis-associated encephalopathy - a prospective, pilot observational study. PLoS ONE. (2019) 14:e0211184. doi: 10.1371/journal.pone.0211184

93. Marinoni M, Ginanneschi A, Forleo P, Amaducci L. Technical limits in transcranial Doppler recording: inadequate acoustic windows. Ultrasound Med Biol. (1997) 23:1275-7. doi: 10.1016/S0301-5629(97)00077-X

94. Sharshar T, Carlier R, Bernard F, Guidoux C, Brouland J-P, Nardi O, et al. Brain lesions in septic shock: a magnetic resonance imaging study. Intensive Care Med. (2007) 33:798-806. doi: 10.1007/s00134-007-0598-y

95. Polito A, Eischwald F, Maho A-L, Polito A, Azabou E, Annane D, et al. Pattern of brain injury in the acute setting of human septic shock. Crit Care. (2013) 17:R204. doi: 10.1186/cc12899

96. Suchyta MR, Jephson A, Hopkins RO. Neurologic changes during critical illness: brain imaging findings and neurobehavioral outcomes. Brain Imaging Behav. (2010) 4:22-34. doi: 10.1007/s11682-009-9082-3

97. Stender J, Gosseries O, Bruno M-A, Charland-Verville V, Vanhaudenhuyse A, Demertzi A, et al. Diagnostic precision of PET imaging and functional MRI in disorders of consciousness: a clinical validation study. Lancet. (2014) 384:514-22. doi: 10.1016/S0140-6736(14)60042-8

98. Kampe KKW, Rotermund R, Tienken M, Thomalla G, Regier M, Klutmann S, et al. Diagnostic value of positron emission tomography combined with computed tomography for evaluating critically ill neurological patients. Front Neurol. (2017) 8:33. doi: 10.3389/fneur.2017.00033

99. Di Perri C, Bahri MA, Amico E, Thibaut A, Heine L, Antonopoulos G, et al. Neural correlates of consciousness in patients who have emerged from a minimally conscious state: a cross-sectional multimodal imaging study. Lancet Neurol. (2016) 15:830-42. doi: 10.1016/S1474-4422(16)00111-3

100. Azabou E, Fischer C, Guerit JM, Annane D, Mauguiere F, Lofaso F, et al. Neurophysiological assessment of brain dysfunction in critically ill patients: an update. Neurol Sci. (2017) 38:715-26. doi: 10.1007/s10072-0 $17-2824-x$

101. Young GB, Bolton CF, Archibald YM, Austin TW, Wells GA. The electroencephalogram in sepsis-associated encephalopathy. $J$ Clin Neurophysiol. (1992) 9:145-52. doi: 10.1097/00004691-199201000-00016

102. Azabou E, Magalhaes E, Braconnier A, Yahiaoui L, Moneger G, Heming N, et al. Early standard electroencephalogram abnormalities predict mortality in septic intensive care unit patients. PLoS ONE. (2015) 10:e0139969. doi: 10.1371/journal.pone.0139969

103. Gilmore EJ, Gaspard N, Choi HA, Cohen E, Burkart KM, Chong DH, et al. Acute brain failure in severe sepsis: a prospective study in the medical intensive care unit utilizing continuous EEG monitoring. Intens Care Med. (2015) 41:686-94. doi: 10.1007/s00134-015-3709-1

104. Zauner C, Gendo A, Kramer L, Kranz A, Grimm G, Madl C. Metabolic encephalopathy in critically ill patients suffering from septic or nonseptic multiple organ failure. Crit Care Med. (2000) 28:1310-15. doi: 10.1097/00003246-200005000-00009

105. Zauner C, Gendo A, Kramer L, Funk GC, Bauer E, Schenk P, et al. Impaired subcortical and cortical sensory evoked potential pathways in septic patients. Crit Care Med. (2002) 30:1136-9. doi: 10.1097/00003246-20020 5000-00030

106. Rinaldi S, Consales G, De Gaudio AR. Changes in auditory evoked potentials induced by postsurgical sepsis. Minerva Anestesiol. (2008) 74:245-50.
107. Azabou E, Rohaut B, Heming N, Magalhaes E, Morizot-Koutlidis R, Kandelman S, et al. Early impairment of intracranial conduction time predicts mortality in deeply sedated critically ill patients: a prospective observational pilot study. Ann Intens Care. (2017) 7:63. doi: 10.1186/s13613-017-0290-5

108. Grände P-O. Critical evaluation of the lund concept for treatment of severe traumatic head injury, 25 years after its introduction. Front Neurol. (2017) 8:315. doi: 10.3389/fneur.2017.00315

109. Pfister D, Schmidt B, Smielewski P, Siegemund M, Strebel SP, Rüegg S, et al. Intracranial pressure in patients with sepsis. Acta Neurochir Suppl. (2008) 102:71-5. doi: 10.1007/978-3-211-85578-2_14

110. Tariq A, Aguilar-Salinas P, Hanel RA, Naval N, Chmayssani M. The role of ICP monitoring in meningitis. Neurosurg Focus. (2017) 43:E7. doi: 10.3171/2017.8.FOCUS17419

111. Glimåker $\mathrm{M}$, Johansson $\mathrm{B}$, Halldorsdottir $\mathrm{H}$, Wanecek $\mathrm{M}$, ElmiTerander A, Ghatan $\mathrm{PH}$, et al. Neuro-intensive treatment targeting intracranial hypertension improves outcome in severe bacterial meningitis: an intervention-control study. PLoS ONE. (2014) 9:e91976. doi: 10.1371/journal.pone.0091976

112. Funk DJ, Kumar A, Klar G. Decreases in cerebral saturation in patients with septic shock are associated with increased risk of death: a prospective observational single center study. J Intens Care. (2016) 4:42. doi: $10.1186 / s 40560-016-0167-y$

113. Wood MD, Maslove DM, Muscedere JG, Boyd JG. The physiological determinants of near-infrared spectroscopy-derived regional cerebral oxygenation in critically ill adults. ICMx. (2019) 7:23. doi: 10.1186/s40635-019-0247-0

114. Zimmer R, Lang R, Oberdörster G. Effects of catecholamine infusions on cerebral blood flow and oxygen consumption of the isolated perfused dog brain. Stroke. (1974) 5:397-405. doi: 10.1161/01.STR.5.3.397

115. King BD, Sokoloff L, Wechsler RL. The effects of l-epinephrine and 1norepinephrine upon cerebral circulation and metabolism in man. J Clin Invest. (1952) 31:273-9. doi: 10.1172/JCI102603

116. Hahn GH, Heiring C, Pryds O, Greisen G. Cerebral vascular effects of hypovolemia and dopamine infusions: a study in newborn piglets. Acta Paediatr. (2012) 101:736-42. doi: 10.1111/j.1651-2227.2012.0 2666. $\mathrm{x}$

117. Hahn GH, Hyttel-Sorensen S, Petersen SM, Pryds O, Greisen G. Cerebral effects of commonly used vasopressor-inotropes: a study in newborn piglets. PLoS ONE. (2013) 8:e63069. doi: 10.1371/journal.pone.0063069

118. Tuor UI, Edvinsson L, McCulloch J. Catecholamines and the relationship between cerebral blood flow and glucose use. Am J Physiol. (1986) 251:H82433. doi: 10.1152/ajpheart.1986.251.4.H824

119. Russell JA, Walley KR, Singer J, Gordon AC, Hébert PC, Cooper DJ, et al. Vasopressin versus norepinephrine infusion in patients with septic shock. $N$ Eng J Med. (2008) 358:877-87. doi: 10.1056/NEJMoa067373

120. Pereira AJ, Jeger V, Fahrner R, Djafarzadeh S, Lensch M, Takala J, et al. Interference of angiotensin II and enalapril with hepatic blood flow regulation. Am J Physiol Gastrointestinal Liver Physiol. (2014) 307:G655-63. doi: 10.1152/ajpgi.00150.2014

121. MacKenzie ET, McGeorge AP, Graham DI, Fitch W, Edvinsson L, Harper AM. Effects of increasing arterial pressure on cerebral blood flow in the baboon: influence of the sympathetic nervous system. Pflugers Arch. (1979) 378:189-95. doi: 10.1007/BF00592735

122. Greenfield JC, Tindall GT. Effect of norepinephrine, epinephrine, and angiotensin on blood flow in the internal carotid artery of man. JClin Invest. (1968) 47:1672-84. doi: 10.1172/JCI105858

123. Olesen J. The effect of intracarotid epinephrine, norepinephrine, and angiotensin on the regional cerebral blood flow in man. Neurology. (1972) 22:978-87. doi: 10.1212/WNL.22.9.978

124. Annane D, Vignon P, Renault A, Bollaert P-E, Charpentier C, Martin C, et al. Norepinephrine plus dobutamine versus epinephrine alone for management of septic shock: a randomised trial. Lancet. (2007) 370:676-84. doi: 10.1016/S0140-6736(07)61344-0

125. De Backer D, Biston P, Devriendt J, Madl C, Chochrad D, Aldecoa C, et al. Comparison of dopamine and norepinephrine in the treatment of shock. $N$ Engl J Med. (2010) 362:779-89. doi: 10.1056/NEJMoa0907118 
126. De Backer D, Aldecoa C, Njimi H, Vincent J-L. Dopamine versus norepinephrine in the treatment of septic shock: a meta-analysis*. Crit Care Med. (2012) 40:725-30. doi: 10.1097/CCM.0b013e318 23778ee

127. Khanna A, English SW, Wang XS, Ham K, Tumlin J, Szerlip H, et al. Angiotensin II for the treatment of vasodilatory shock. N Engl J Med. (2017) 377:419-30. doi: 10.1056/NEJMoa1704154

128. Lamontagne F, Day AG, Meade MO, Cook DJ, Guyatt GH, Hylands M, et al. Pooled analysis of higher versus lower blood pressure targets for vasopressor therapy septic and vasodilatory shock. Intens Care Med. (2018) 44:12-21. doi: 10.1007/s00134-017-5016-5
Conflict of Interest: The authors declare that the research was conducted in the absence of any commercial or financial relationships that could be construed as a potential conflict of interest.

Copyright (๑ 2020 Heming, Mazeraud, Azabou, Moine and Annane. This is an open-access article distributed under the terms of the Creative Commons Attribution License (CC BY). The use, distribution or reproduction in other forums is permitted, provided the original author(s) and the copyright owner(s) are credited and that the original publication in this journal is cited, in accordance with accepted academic practice. No use, distribution or reproduction is permitted which does not comply with these terms. 